\title{
Exploring specific primers targeted against different genes for a multiplex PCR for detection of Listeria monocytogenes
}

\author{
Ashwani Kumar • Sunita Grover • \\ Virender Kumar Batish
}

Received: 18 January 2014/ Accepted: 29 April 2014/Published online: 21 May 2014

(C) The Author(s) 2014. This article is published with open access at Springerlink.com

\begin{abstract}
The efficacy of six different sets of primers targeted against $16 S$ rRNA and virulence genes such as 'iap', ' $h l y$ ' and ' $p r f$ ' was evaluated in separate PCR assays. The primer pairs targeted against $16 S$ rRNA resulted into amplification of $1.2 \mathrm{~kb}$ PCR product. However, sets of primers targeted against different regions of 'iap' produced 371 and $660 \mathrm{bp} \mathrm{PCR} \mathrm{products,} \mathrm{respectively.} \mathrm{The} \mathrm{primer}$ pair targeted against 'prf' gene could produce $508 \mathrm{bp}$ product. Three primer pairs targeted against different regions of ' $h l y$ ', i.e., ' $h l y$ ', ' $h l y A$ ' and ' $h l y K{ }^{\prime}$ ' were able to amplify 713,276 and 384 bp products, respectively. The PCR conditions were also optimized in respect of two internal sets of primers falling within 'iap' and ' $h l y$ ' genes that amplified 119 and 188 bp products to verify the PCR results obtained with respective external sets of primers. Three different combinations involving four sets of primers based on $16 S$ rRNA, 'iap', 'hly' and 'prf' were explored in respective multiplex PCR assays in order to select a suitable combination. Combination 1 and 3 worked successfully as revealed by amplification of all the four bands of expected sizes on agarose gel. However, while optimizing the different parameters for developing a functional multiplex PCR, it was observed that in both these combinations, only two of the amplified products, i.e., $1.2 \mathrm{~kb}$ and $713 \mathrm{bp}$ could be invariably detected. Hence, these two primers were combined in the multiplex PCR and the
\end{abstract}

A. Kumar · S. Grover · V. K. Batish ( $₫)$

Molecular Biology Unit, Dairy Microbiology Division, National Dairy Research Institute, Karnal 132001, Haryana, India

e-mail: vkbatish@gmail.com

\section{A. Kumar}

Department of Biotechnology, Seth Jai Parkash Mukand Lal Institute of Engineering and Technology, Radaur,

Yamuna Nagar 135133, Haryana, India conditions were optimized for application in dairy foods for detection of Listeria monocytogenes.

Keywords Primers - Evaluation - Multiplex PCR . Listeria monocytogenes - Detection · Dairy foods

\section{Introduction}

Listeria monocytogenes, a high-risk emerging food pathogen, has recently assumed lot of interest as a result of its association with several outbreaks of listeriosis across the world through implication with wide variety of foods, both raw and processed (Dalton et al. 1997; CDC 2000; Kumar et al. 2012, 2014). The reports available in India regarding the incidence of L. monocytogenes have been analyzed by many workers (Khan et al. 2011; Vinothkumar et al. 2013; Trimulai 2013). Moreover, the occurrence of L. monocytogenes in India has been underreported in many cases because of the inefficient surveillance and monitoring system. The ability of this emerging food pathogen to survive and grow in many foods during processing and storage has been attributed to its ubiquitous nature, resistance to diverse environmental conditions such as low $\mathrm{pH}$ and high salt concentrations and its microaerobic and psychrotrophic nature. The psychrotrophic nature to grow and survive at a wide range of temperature $\left(2-40{ }^{\circ} \mathrm{C}\right)$ in or on foods for prolonged periods under adverse conditions has made L. monocytogenes a major concern for the agrifood industry during the last decade. Mandatory compliance issued by food and drug administration for zero tolerance ruling for this organism in processed/ready-to-eat foods has emphasized the need for development of molecular-based rapid methods for detection of $L$. monocytogenes. 
Keeping in view the limitations associated with conventional, immunological and nucleic acid probe assays, several PCR-based formats have been evolved for detection of $L$. monocytogenes (Kumar et al. 2012). In this context, the gene cassette along with 'iap' gene involved in pathogenicity of $L$. monocytogenes has been made real targets for its rapid detection by means of PCR-based assays. The expression of three different L. monocytogenes virulence genes (iap, hly and $\operatorname{prf} \mathrm{A}$ ) was examined by several investigators to determine the suitable target for specific DNA amplification using gene-specific primers. The 'iap' gene encodes for a $60 \mathrm{kDa}$ basic extracellular protein (p60) which acts as murein hydrolase involved in septum formation (Wuenscher et al. 1993). The exact role of p60 in invasion is, however, still not clear. Another virulence gene hemolysin encodes two virulence factors involved in the lysis of vacuole namely listerolysin $\mathrm{O}$ (LLO) and phosphatidylinositol-specific phospholipase C (PI-PLC) by means of pore-forming activity and hydrolysis of glycophosphatidyl inositol anchors, thereby, leading to escape of organisms from the vacuole in primary macrophages (Portnoy et al. 1992; Sheehan et al. 1994). The use of $16 S$ rRNA gene as a distinct signature for a bacterial species has become the method of choice for identifying and differentiating microorganisms because of multiple copies $\left(10^{4}\right)$ of rRNA present in cell (Wang et al. 1992). Based on 16S rRNA gene sequences, several PCR assays have been developed for detection of Listeria monocytogenes at both genus and species level (Wiedmann et al. 1993; Czajka et al. 1993). The virulence gene ' $h l y A$ ' has also been targeted by different investigators for the development of PCR-based assays intended for detection of L. monocytogenes (Deneer and Boychuk 1991; Fluit et al. 1993; Norton and Batt 1999). The 'iap' gene common to all members of the genus Listeria had also been chosen as a suitable target after finding that there were conserved gene portions at $5^{\prime}$ and $3^{\prime}$ ends, while internal portions are highly specific (Bubert et al. 1992). In this investigation, we evaluated the efficacy of a few selected pair of primers individually and in different combinations with the objective of developing a reliable Multiplex PCR for detection and identification of L. monocytogenes.

\section{Materials and methods}

Bacterial cultures and their maintenance

The bacterial cultures used in this investigation included pathogenic strains of L. monocytogenes along with other cultures. Listeria monocytogenes ATCC 7644 was purchased from Thermo Scientific, UK and L. monocytogenes Scott A was procured from DM Division, NDRI, Karnal. The cultures used in this study were propagated in BHI (brain heart infusion)/TSB (Trypticase soya broth) at $37{ }^{\circ} \mathrm{C}$ for $18 \mathrm{~h}$. The cultures were preserved on BHI/Trypticase soya agar slants and stored in refrigerator or as glycerol stocks stored at $-70{ }^{\circ} \mathrm{C}$ ultra low deep freezer (New Brunswick Scientific, USA) until further use. The cultures were activated in $\mathrm{BHI}$ broth prior to use by sub-culturing at biweekly intervals.

\section{Preparation of template DNA}

\section{Broth cultures}

The template/genomic DNA was prepared from broth cultures of Listeria monocytogenes by following boiled lysate method (Witham et al. 1996) as well as the method of Pospiech and Neikmann (1995). The boiled lysate was prepared by harvesting the overnight grown culture of the test organism followed by heating the bacterial suspension in 50 MilliQ water for $5 \mathrm{~min}$ in a boiling water bath and then centrifuging for $5 \mathrm{~min}$ at $10,000 \mathrm{rpm}$ to separate the supernatant containing DNA. For Pospeich and Neikmann's method, the cells were harvested from one $\mathrm{ml}$ of overnight grown cultures of L. monocytogenes and resuspended in $0.5 \mathrm{ml}$ of SET buffer $(75 \mathrm{mM} \mathrm{NaCl}, 25 \mathrm{mM}$ EDTA, $20 \mathrm{mM}$ Tris) and lysozyme was added at a concentration of $1 \mathrm{mg} / \mathrm{ml}$ (25 mM Tris, lysozyme, $10 \mathrm{mg}, 5 \mathrm{M}$ $\mathrm{NaCl}$ ) followed by incubation at $37{ }^{\circ} \mathrm{C}$ for $1 \mathrm{~h}$. The subsequent step was the addition of $1 / 10$ th volume of $10 \%$ SDS and $0.5 \mathrm{mg} / \mathrm{ml}$ of proteinase $\mathrm{K}$ and incubation further continued for $2 \mathrm{~h}$ at $55^{\circ} \mathrm{C}$. One-third volume of $5 \mathrm{M} \mathrm{NaCl}$ and one volume of chloroform were added and incubated at room temperature for $30 \mathrm{~min}$ with frequent inversions. The samples were centrifuged and upper aqueous phase transferred to a new tube and the DNA was precipitated by adding one volume of isopropanol or two volumes of ethanol. The DNA was pelleted, dried and dissolved in TER buffer containing $10 \mu \mathrm{g} / \mathrm{ml}$ of RNase A.

\section{PCR assay}

The PCR amplification for detection of Listeria monocytogenes was performed using Eppendorf master cycler gradient, 5331, Germany. The selected oligonucleotide primers for detection of Listeria monocytogenes were got custom synthesized (Bangalore Genei, India). The description of the primer pairs used in this study is given in Table 1 . The PCR assay was performed in $25 \mu$ reaction mixture comprising of $100 \mathrm{ng}$ of template DNA, $10 \times$ PCR buffer (containing $\mathrm{MgCl}_{2}$ ), $0.2 \mathrm{mM}$ (each of primers), $0.2 \mathrm{mM}$ (each) dNTPs and 1 unit of Taq polymerase (Boehronger Mannheim). Appropriate positive and negative controls with each reaction were also set up. The PCR cycling parameters used for each set of primers are as per 
Table 1 Description of the primers used in the present investigation

\begin{tabular}{|c|c|c|c|c|c|}
\hline S. no. & Target gene & Primers & Primer sequence & $\begin{array}{l}\text { Size of amplified } \\
\text { product (bp) }\end{array}$ & References \\
\hline 1 & $16 S$ rRNA & $\begin{array}{l}\mathrm{Lm} 3 \\
\mathrm{Lm} 5\end{array}$ & 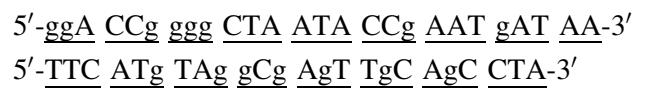 & 1,200 & Wiedmann et al. (1993) \\
\hline 2 & iap & $\begin{array}{l}\text { ELMIAPF } \\
\text { ELMIAPR }\end{array}$ & $\begin{array}{l}5^{\prime}-\underline{\mathrm{CAA}} \\
5^{\prime}-\mathrm{ACA} \\
\underline{\mathrm{ACT}}\end{array}$ & 371 & Klein and Juneja (1997) \\
\hline & & $\begin{array}{l}\text { Mono A } \\
\text { Lis } 1 \mathrm{~B}\end{array}$ & $\begin{array}{l}5^{\prime}-\underline{\mathrm{CAA}} \frac{\mathrm{ACT}}{5^{\prime}-\underline{\mathrm{gCT}}} \frac{\underline{\mathrm{AAC}}}{\mathrm{gCg}} \underline{\underline{\mathrm{ACC}}} \underline{\mathrm{gAA}} \underline{\mathrm{gCC}} \underline{\mathrm{AAC}-3^{\prime}}\end{array}$ & 660 & Bubert et al. (1999) \\
\hline 3 & Hemolysin & $\begin{array}{l}\text { Hly } 1 \\
\text { Hly } 2\end{array}$ & $\begin{array}{l}5^{\prime} \text {-ATT } \frac{\text { TTC }}{\text { CCT }} \frac{\text { TCA }}{\text { CTg }} \frac{\text { ATT }}{5^{\prime}-\underline{\text { CAC }}} \underline{\underline{\text { TCA }}} \underline{\underline{\text { gCA }}} \underline{\text { TTg }} \underline{\text { ATT }} \underline{\text { TgC }} \underline{\text { CA- } 3^{\prime}}\end{array}$ & 276 & Cooray et al. (1994) \\
\hline & & $\begin{array}{l}\text { ELMHLYF } \\
\text { ELMHLYR }\end{array}$ & $\begin{array}{l}5^{\prime}-\underline{\mathrm{TCC}} \underline{\mathrm{gCC}} \underline{\mathrm{TgC}} \text { AAg } \frac{\mathrm{TCC}}{\mathrm{TAA}} \underline{\mathrm{gA}-3^{\prime}} \\
5^{\prime}-\underline{\mathrm{gCg}} \underline{\mathrm{CTT}} \underline{\mathrm{gCA}} \underline{\mathrm{ACT}} \underline{\mathrm{gCT}} \underline{\underline{\mathrm{CTT}}} \underline{\mathrm{TA}-3^{\prime}}\end{array}$ & 713 & Klein and Juneja (1997) \\
\hline & & $\begin{array}{l}\text { ILMHLYF } \\
\text { ILMHLYR }\end{array}$ & 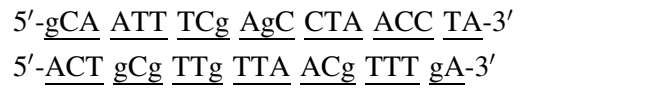 & 188 & Klein and Juneja (1997) \\
\hline & & $\begin{array}{l}\text { HF9 } \\
\text { HR9 }\end{array}$ & 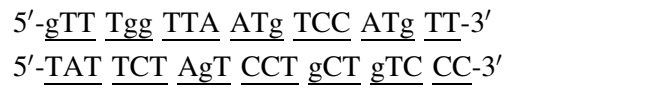 & 384 & Wagner et al. (2000) \\
\hline 4 & $\operatorname{prf} A$ & $\begin{array}{l}\text { ELMPRFF } \\
\text { ELMPRFR }\end{array}$ & 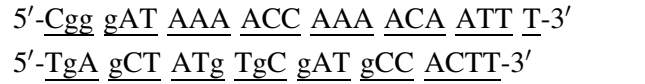 & 508 & Klein and Juneja (1997) \\
\hline
\end{tabular}

the published literature and will be described in the "Results and Discussion".

\section{Multiplex PCR assay}

For developing a multiplex PCR assay for detection of $L$. monocytogenes in foods, four sets of different primers evaluated previously were tried in three different combinations simultaneously in one assay.

Optimization of multiplex PCR amplification conditions

Amplification conditions were optimized with respect to annealing temperature (Gradient PCR using $60{ }^{\circ} \mathrm{C}$ with a gradient of $2{ }^{\circ} \mathrm{C}$ ), Taq polymerase concentration (0.5-3.0 units), $\mathrm{MgCl}_{2}$ concentration ( $\left.1 \mathrm{mM}-3.0 \mathrm{mM}\right)$, Primer concentration (25 ng-100 ng), annealing time (30, 45 and $60 \mathrm{~s})$, extension time (30 s and $1 \mathrm{~min})$ and number of cycles $(25,30,35$ and 40) for the four sets of primers used in the multiplex PCR assay.

\section{Analysis of PCR products}

The PCR amplified products were electrophoresed on $2 \%$ agarose gel containing $0.5 \mu \mathrm{g} / \mathrm{ml}$ of ethidium bromide. The gel was visualized under UV transilluminator and photographed using Polaroid 667 packfilm with MP4 system polaroid camera (Photodyne, USA). The molecular size marker consisted of $100 \mathrm{bp}$ DNA ladder comprising of 100-1,000 bp bands (Bangalore Genei, India).

\section{Results and discussion}

Evaluation of primers for Listeria monocytogenes

During the initial part of this study, we tested the efficacy of six different sets of primers targeted against $16 \mathrm{~S} r R N A$ (genus specific) and virulence genes such as 'iap', ' $h l y$ ' and 'prf' (L. monocytogenes specific) in their respective PCR assays using common PCR cycling parameters as their annealing temperatures were pretty close. These include initial denaturation at $95{ }^{\circ} \mathrm{C}$ for $4 \mathrm{~min}$ followed by 35 cycles each of denaturation at $94{ }^{\circ} \mathrm{C}$ for $30 \mathrm{~s}$, annealing at $60{ }^{\circ} \mathrm{C}$ for $1 \mathrm{~min}$ and extension at $72{ }^{\circ} \mathrm{C}$ for $1 \mathrm{~min}$ and the final extension of $72{ }^{\circ} \mathrm{C}$ for $5 \mathrm{~min}$. The results pertaining to the amplification of the Listeria monocytogenes-specific template DNA extracted by Pospiech and Neikmann's method/boiled lysate with individual primers pairs have been presented in Figs. 1 and 2.

Genus-specific primers for Listeria spp.

\section{S rRNA-based primers Lm3/Lm5}

$16 S$ rRNA has been targeted in the identification of a number of bacteria both at genus and species level by exploring the conserved and variable regions of the gene. (Gopo et al. 1988; Maureau et al. 1989). The choice for targeting $16 \mathrm{~S} r R N A$ gene has been dictated by the presence in microorganisms of multiple copies $\left(10^{4}\right)$ of rRNA, thereby, increasing the ease of signal generation of the assays. Specific DNA probes or PCR primers have been 
$\begin{array}{lllllllllllll}M & 1 & 2 & 3 & 4 & 5 & 6 & 7 & 8 & 9 & 10 & 11 & 12\end{array}$

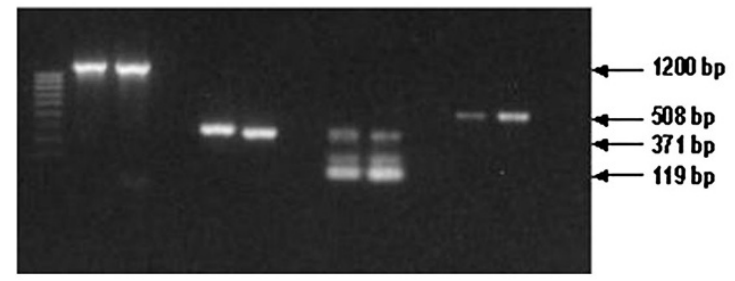

Lanes: M; 100bp Marker; 1-3 (16s rRNA primers): 1, LmATCC 7644 2, Lm Scott A; 3, Negative control; 4-6 ('iap' primers):4, Lm ATCC7644 5, Lm Scott A; 6, Negative Control; 7-9 (Internal 'iap' primers): 7, Im ATCC 7644; $8 \mathrm{Lm}$ Scott A; 9, Negative Control; 10-12 ('prf' primers) : 10, Lm ATCC7644; 11, Lm Scott A: 12, Negative control.

Fig. 1 Evaluation of different sets of primers targeted for detection of Listeria and Listeria monocytogenes by PCR amplification

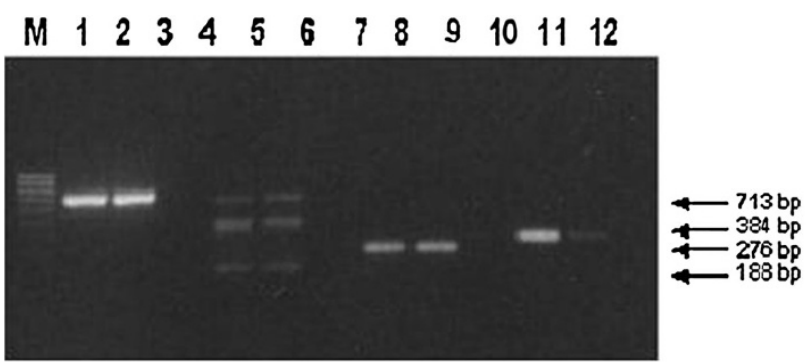

Lanes: M; 100 bp Marker; 1-3 ('Hly' primers): 1, Lm ATCC 7644 ; 2, Lm Scott A; 3, Negative control; 4-6 (Internal ' $\mathrm{H}$ y' primers): 4, Lm ATCC7644 ;5, Lm Scott A; 6. Negative Control; 7-9 ('Hly A' primers): 7. Lm ATCC 7644; 8, Lm Scott A: 9, Negative Control; 10-12 ('Hy K9' primers) : 10, Lm ATCC $7644: 11$, Lm Scott A: 12, Negative control

Fig. 2 Evaluation of primers using different regions of hemolysin gene of Listeria monocytogenes

designed from variable ribosomal RNA regions and used for the detection of specific target cells, e.g., the detection of L. monocytogenes (Wang et al. 1991), Aeromonas (Barry et al. 1990), Lactic acid bacteria (Klijn et al. 1991) and Salmonella species (Lin and Tsen 1996). Prompted by the advantages offered by $16 \mathrm{~S}$ rRNA, we also targeted this gene in our study for exploring a set of primers based on the $16 S$ rRNA for determining its suitability in a PCR assay for detection of Listeria.

The first primer targeted against $16 \mathrm{~S} r R N A$ included in this study was intended for detection of all types of Listeria at genus level. A PCR assay was standardized using the primer pair in combination with template DNA from two of the Listeria monocytogenes strains ATCC and Scott A. An amplified PCR product of 1,200 bp was detected on the agarose gel with template from both the strains (Fig. 1, Lanes 1 and 2). The PCR amplification conditions include initial denaturation at $95{ }^{\circ} \mathrm{C}$ for $4 \mathrm{~min}$ followed by 35 cycles each of denaturation at $94{ }^{\circ} \mathrm{C}$ for $30 \mathrm{~s}$, annealing at $60{ }^{\circ} \mathrm{C}$ for $1 \mathrm{~min}$ and extension at $72{ }^{\circ} \mathrm{C}$ for $1 \mathrm{~min}$ and the final extension of $72{ }^{\circ} \mathrm{C}$ for $5 \mathrm{~min}$. The primer pair appears to be highly specific for Listeria only at these amplifications parameters, as no specific bands could not be observed.

Our results in this regard are consistent with the earlier findings of Wiedmann et al. (1993) who also achieved the amplification of $1.2 \mathrm{~Kb}$ fragment with the help of primers $\mathrm{Lm} 3$ and Lm5 in their PCR assay used in conjunction with LCR with all Listeria spp. except $L$. grayi. This assay was based on a single base pair difference in the V9 region of the sequence of the genes coding for ribosomal RNA which distinguished L. monocytogenes from other closely related Listeria spp. The results from our study clearly demonstrate that the two PCR primers used in the PCR assay were genus specific since the $1.2 \mathrm{~Kb}$ amplicon could not be detected in any other organism other than Listeria.

16S $r R N A$ was also explored previously (Wang et al. 1991, 1992) for detection of Listeria monocytogenes in foods spiked with the target organism. They used pair of primers based on a unique region in the $16 S$ rRNA sequence in L. monocytogenes to yield a specific nucleic acid probe. The method was found to be extremely sensitive as it could detect as low as $2-20 \mathrm{cfu} / \mathrm{ml}$ of $L$. monocytogenes in pure cultures and as few as $4-40 \mathrm{cfu}$ in inoculated diluted food samples.

Species-specific primers targeted against virulence genes of L. monocytogenes

The pathogenicity of L. monocytogenes is associated with a number of virulence factors which are encoded on a multigene family common to all Listeria monocytogenes strains. Some of these virulence genes could also be very attractive candidates for targeting in the development of PCR-based assays for detection of L. monocytogenes. In this study, we evaluated five sets of primers based on 'iap', ' $h l y$ ' and ' $p r f$ ' genes in their respective PCR assays. The results pertaining to the suitability of these primers are discussed below.

\section{'iap'-based primers ELMIAPF/R}

For this investigation, we had specifically chosen 'iap' gene common to all members of the genus Listeria as target because the comparison of all 'iap' genes has indicated that there were conserved regions at $5^{\prime}$ and $3^{\prime}$ ends, while the internal portions are highly specific (Bubert et al. 1992). The 'iap' gene of L. monocytogenes encodes the major extracellular protein (P60) (Kuhn and Goebel 1989), which has been shown to be basically an essential murein hydrolase required for adherence/invasion of the organism to the targeted eucaryotic cell. It has been recently shown that the corresponding iap gene portion is also hypervariable in length in different isolates belonging to the same 
serotypes, thereby, can help in identification of different strains of L. monocytogenes.

In order to delineate the species identity of Listeria spp., some Listeria monocytogenes-specific primers targeted against selected virulence genes were initially explored individually in the study for PCR assays. The first primer pair selected for the purpose was targeted against 'iap' gene as used previously by Klein and Juneja (1997). The PCR amplification conditions were exactly the same as indicated above for $16 \mathrm{~S} r R N A$-based PCR assay. Agarose gel picture as shown in Fig. 1 (Lanes 4 and 5) revealed a PCR amplified product of $371 \mathrm{bp}$ size with template DNA from both the strains of Listeria monocytogenes used in the study. In order to explore the possibility of confirming the authenticity of PCR products ( $371 \mathrm{bp)}$ ) of above 'iap'-based primers (external) specific for Listeria monocytogenes, a pair of primers targeted against internal region of 'iap' gene with the amplified PCR product was also tested in this study. The template used in the PCR assay based on internal 'iap' primers was the amplified $371 \mathrm{bp}$ product obtained from the previous PCR assay. The PCR assay using internal 'iap' primers and the amplified product of the external 'iap'-based PCR assay resulted into the amplification of $119 \mathrm{bp}$ product as can be evidenced from Fig. 1 (Lanes 7 and 8). However, two additional non-specific bands were also detected on the gel albeit at a relatively low intensity. One such band corresponds with the $371 \mathrm{bp}$ product of external 'iap'-based PCR indicating the possible carry over of the template DNA. The nested PCR conditions used in the study were optimized that resulted into 119 bp product only using $0.5 \mu \mathrm{l}$ of $1: 10$ diluted PCR amplified product from external iap primers (data not shown). Our results pertaining to amplification of the targeted DNA with 'iap'-based primers are in close agreement with those of Klein and Juneja (1997) who had previously used there primers for RT-PCR instead of direct PCR with the sole objective of detecting viable cells of $L$. monocytogenes. The RT-PCR assay developed by these investigators could amplify a $371 \mathrm{bp}$ product with ELMIAPF/R from only the viable cells when cDNA synthesized from mRNA of L. monocytogenes was used as the template. However, in our study these primers were intended to amplify L. monocytogenes template DNA through direct PCR for subsequent application of the assay in detection of the targeted organism in raw milk and paneer which do not require any harsh processing treatments. Our results with regard to the use of internal primers-based 'iap' gene are also comparable to those of Klein and Juneja (1997), although the purpose of using these primers in the two studies was different. Klein and Juneja (1997) had used this internal set of primers just to produce a probe for confirmation of their RTPCR results for detection of viable L. monocytogenes. However, we have used these primers for confirming the specificity of $371 \mathrm{bp}$ product. 'iap’-based primers (Mono A and Lis $1 B$ )

Another set of primers targeted against a different region of 'iap' was also included in our study for determining their possible application in detection of Listeria monocytogenes by PCR assay. The PCR assay set up with this primer pair Mono A and Lis 1B could amplify a 660 bp product with template from Listeria monocytogenes. Lis 1 set of primers in the assay worked reasonably well with the PCR amplification parameters as used for other 'iap'/'PrfA'-based PCR assays (data not shown). Our PCR results obtained with Mono A and Lis1B set of primers are consistent with the observations recorded by Bubert et al. (1999) who could also get the amplification of the $660 \mathrm{bp}$ product with this set of primers and exploited it for development of a multiplex PCR assay for L. monocytogenes.

\section{'prfA'-based primers ELMPRFF/R}

Since the virulence genes in Listeria monocytogenes are coregulated by 'prfA' gene which codes for a $27.1 \mathrm{kDa}$ protein (Chakraborty et al. 1992) which positively regulate all the virulence genes, this gene can also be targeted for detection of L. monocytogenes by PCR. We also explored 'prfA' in the PCR assay using a pair of primers which resulted into the amplification of 508 bp product as seen in Fig. 1 (Lanes 10 and 11). Our results in this regard are again exactly compatible with those of Klein and Juneja (1997) who could also obtained 508 bp products in RTPCR-based assay used for detection of L. monocytogenes.

Primers targeted against ' $h l y$ ' gene

Listeria monocytogenes is also capable of producing hemolysins which are involved in the lysis of vacuole and the erythrocytes. The main factor involved in the lysis of the vacuole is the protein that has pore forming activity. 'Listeriolysin O', a $58 \mathrm{kDa}$ protein, is encoded on ' $h l y \mathrm{~A}$ ' gene. ' $H l y A$ ' gene has also been targeted for development of PCRbased assays intended for detection of L. monocytogenes. In this study, we used three sets of primers targeted against different regions of ' hly' gene of Listeria monocytogenes as used previously by other workers and evaluated their efficacy in their respective PCR assays. The results pertaining to the same have been presented in Fig. 2.

\section{'hly'-based primers ELMHLYF/R}

The primer pair namely ELMHLYF/R targeted against ' $h l y$ ' gene when used in the PCR assay produced an amplified product of $713 \mathrm{bp}$ with template DNA from Listeria monocytogenes (Fig. 2, Lanes 1 and 2). The PCR amplification conditions were exactly the same as those used for 
16S rRNA-, 'iap'- and 'PrfA'-based PCR assays. Here also to further check the authenticity of the $713 \mathrm{bp}$ product obtained with $h l y$-based primer set, another pair of primers namely ILM $H L Y F / R$ representing the internal region of 713 bp amplified product was also tested separately in a different PCR assay using the $713 \mathrm{bp}$ amplified product as template and the same amplification parameters as described for $h l y$-based PCR assay. This resulted into the amplification of $188 \mathrm{bp}$ product falling within the internal region of 713 bp product as shown in Fig. 2 (Lanes 4 and 5). However, two more additional non-specific bands one corresponding with $713 \mathrm{bp}$ product along with a smaller band could also be detected on the agarose gel. The nonspecific bands could be eliminated by following the steps as described previously. Our findings in this regard are further supported by similar observations made by Klein and Juneja (1997) who could also achieve a 713 bp product with their RT-PCR assay using ELM $H L Y \mathrm{~F} / \mathrm{R}$ set of primers and $188 \mathrm{bp}$ product with ILM $H L Y \mathrm{~F} / \mathrm{R}$ primers. In this particular case also, these investigators used the internal primers to develop a $L$. monocytogenes-specific probe. On the other hand, the use of these internal primers in our study was intended to confirm the identity of $713 \mathrm{bp}$ product from L. monocytogenes template.

\section{'hlyA'-based primers Hlyl/2}

Another primer pair targeted against ' $h l y \mathrm{~A}$ ' gene when subjected to PCR with the template from Listeria monocytogenes yielded an amplified DNA band of 276 bp as can be revealed from Fig. 2 (Lanes 7 and 8). The PCR conditions used in the assay were more or less similar to those used for the other above-mentioned PCR assays except that an annealing temperature of $55^{\circ} \mathrm{C}$ was used in place of $60{ }^{\circ} \mathrm{C}$. The results pertaining to efficacy of ' $h l y A^{\prime}$ ' gene-based primers with template from L. monocytogenes in the PCR assay used in this study are in close agreement with those of Cooray et al. (1994) who could also detect a $276 \mathrm{bp}$ amplified product in their multiplex PCR assay where they had combined the primers targeted against ' $h l y$ A' gene with those from 'prfA' and 'plcB' genes. However, the PCR cycling conditions used in the two studies were slightly different.

\section{'hly K9'-based primers HF9/HR9}

Since K-9 region derived from the non-coding region of ' $h l y$ ' gene has been found to be highly polymorphic, this particular region can also be explored for developing a PCR assay for distinguishing different strains of L. monocytogenes. This type of assay can be extensively valuable for epidemiological typing. The PCR assay based on hly $K 9$ set of primers produced an amplified PCR product of 384 bp with Listeria monocytogenes template. The PCR results pertaining to the same have been recorded in Fig. 2 (Lanes 10 and 11). Our results in this regard can be substantiated by similar observations made by Wagner et al. (2000) who also recorded the amplification of $384 \mathrm{bp}$ product in their PCR-based study only when L. monocytogenes template was used in the assay.

A critical appraisal of overall PCR results obtained with the respective sets of primers in this study clearly indicates that all the primers worked quite reasonably even under same PCR cycling conditions and hence, there is a possibility of using them simultaneously in conjunction for possible development of a multiplex PCR assay which could authentically detect $L$. monocytogenes in dairy foods rapidly.

Development of multiplex PCR using different combinations of primers for detection of Listeria monocytogenes

After evaluation of individual sets of primers in their respective PCR assays, an attempt was then made to explore different combination of these primers to develop a reliable multiplex PCR assay for detection of Listeria as such or more specifically Listeria monocytogenes. Initially, we tried three combinations involving four different sets of primers in three different multiplex PCR assays using identical PCR parameters. Combination 1 included primer sets targeted against $16 \mathrm{~S} r R N A$, ' $h l y$ ', 'prfA', 'iap' genes, Combination 2 comprised of primers targeted against $16 \mathrm{~S}$ rRNA, 'Lis $1 B$ ', 'prfA', ' $h l y K 9^{\prime}$ and Combination 3 used primer pairs targeted against $16 S$ rRNA, 'Lis 1B', 'prfA' and ' $h l y \mathrm{~A}$ '. The PCR parameters used included initial denaturation at $95{ }^{\circ} \mathrm{C}$ for 4 min followed by 35 cycles each of denaturation at $94{ }^{\circ} \mathrm{C}$ for $30 \mathrm{~s}$, annealing at $58{ }^{\circ} \mathrm{C}$ for $1 \mathrm{~min}$ and extension at $72{ }^{\circ} \mathrm{C}$ for $1 \mathrm{~min}$ and an additional step of extended extension at $72{ }^{\circ} \mathrm{C}$ for $10 \mathrm{~min}$. The results pertaining to the same have been presented in Fig. 3. As is

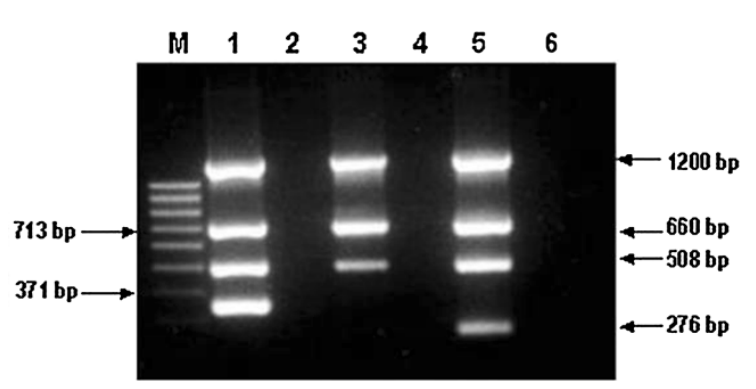

Lanes: M, 100 bp Marker; 1-2, (16S rRNA, Hy, prf, iap primers) : 1 , Lm ATCC 7644; 2 Negative control, 3-4 (16SrRNA, Lis IB, prf, Hy K-9): 3, Lm ATCC 7644; 4, Negative Control; 5-6 (16S rRNA, Lis IB, prf, Hly A): $5, \mathrm{Lm}$ $\operatorname{ATCC} 7644 ; 6$, Negative control.

Fig. 3 Evaluation of different combinations of primers targeted against different genes for detection of Listeria spp. and Listeria monocytogenes by respective multiplex PCR assays 
quite evident from the banding patterns revealed on agarose gel, the multiplex PCR assay set up with primers based on $16 S$ rRNA, hly, prfA and iap (combination 1) amplified the targeted DNA specifically producing four distinct bands of 1,200, 713, 508, $371 \mathrm{bp}$, respectively (Fig. 3, Lane 1), which matched exactly the same with the PCR products obtained with individual primer pairs as described previously. The multiplex PCR with combination 2-based primers could amplify L. monocytogenes template resulting into formation of 1,200, 660 and 508 bp bands, respectively, representing $16 S$ rRNA, Lis $1 B$ and prfA genes (Fig. 3, Lane 3). However, the fourth expected amplified PCR product of size 384 bp representing hly $K 9$ could not be detected on the agarose gel. This discrepancy could possibly be attributed to the use of high annealing temperature in the multiplex PCR which may not be suitable for amplification of K-9 fragment. The combination 3 on the other hand again resulted into the amplification of all the four targeted genes in their respective multiplex PCR assay as indicated by the formation of 1,200, 660, 508 and $276 \mathrm{bp}$ bands on the gel (Fig. 3, Lane 5). A comparative evaluation of the three combinations of the primers in their respective multiplex PCR assays clearly indicates that combination 1 and combination 3 performed reasonably well in their respective multiplex PCR assays and the performance of combination 2 was comparatively lower due to non amplification of $384 \mathrm{bp}$ product. Hence, the latter was not considered for further study. Out of the above combinations, 1 and 3 were selected for further improvements in the study.

The main purpose of developing a multiplex PCR in this study was to minimize the possibility of missing $L$. monocytogenes from detection. With this objective in mind, we had combined four sets of primers including one targeted against genus-specific $16 S$ rRNA and the other three targeted against different regions of virulence genes 'iap', ' $h l y$ ' and 'prfA' for simultaneous amplification of template DNA from L. monocytogenes. Our results in this regard are consistent with similar findings made by Cooray et al. (1994) who also combined three sets of primers targeted against hly $A, p r f \mathrm{~A}$ and $p l c B$ genes in their multiplex PCR assay which could amplify specifically 795, 571 and 276 bp products with $L$. monocytogenes only. It is quite plausible that some L. monocytogenes may lack one or more virulence determinants either because of some mutations or inability of some genes to express under certain conditions. Though the frequency of spontaneous mutations or deletions in these virulence associated genes is not precisely known as yet, we cannot deny the possibility that some mutants like those produced by transposon insertions may exist in nature (Kathariou et al. 1987; Sun et al. 1990) as has been proposed by Cooray et al. (1994). Therefore, it seemed logical and relevant to develop a procedure in which various virulence associated genes could be detected simultaneously in a single step. Working on similar lines, Klein and Juneja (1997) made an attempt to use three pairs of primers targeted against 'hly', 'iap 'and 'prfA' genes simultaneously in their RT-PCR assay to rule out the possibility of false positive results in PCRbased assays for detection of viable L. monocytogenes. However, they were not able to get amplification of all the targeted genes consistently with stronger signal achieved only with primer pair targeted against 'iap' gene, thereby, greatly limiting the applicability of such multiplex RTPCR assay.

\section{Optimization of multiplex PCR based on combination 3}

While further improving the multiplex PCR in terms of using different concentrations of Taq polymerase, dNTPs, primers, manganese chloride, annealing time and number of amplification cycles, it was experienced that two of the amplified products viz. 508 and 276 bp were quite inconsistent in the multiplex PCR and many times either could not be detected on the agarose gel or produced diminished bands (data not shown) that are unable to be visualized. However, the two products namely $1,200 \mathrm{bp}$ based on $16 \mathrm{~S}$ rRNA, 713 bp with ELMHLYF/R and 660 bp based on Lis $1 B$ could always be detected in the multiplex PCR. This inconsistency in the behavior of some primers when used in combination in the multiplex PCR is not an unusual phenomenon due to possible structural interactions between different pieces of oligomers. Although this contention cannot be substantiated as yet, the unequal level of amplifications observed by Klein and Juneja (1997) in their RT-PCR assay using primers targeted against 'iap', ' $p r f$ A' and ' $h l y$ ' genes may indirectly explain the reason for this discrepancy.

In the light of these observations, we finally resorted to develop a multiplex PCR based on two sets of primers one specific for Listeria (16S rRNA) and another for Listeria monocytogenes (' $h l y$ ') for eventual application in dairy foods.

Multiplex PCR based on two sets of primers for detection of Listeria monocytogenes

Since difficulties were encountered in terms of amplification of all the expected products during optimization of a multiplex PCR based on simultaneous use of four sets of primers, efforts were then directed to develop a multiplex PCR assay exploring only two sets of primers i.e. one genus specific and second Listeria monocytogenes specific to get consistent and reproducible results. Two such selected primer pairs which were targeted against $16 S$ rRNA (genus-specific, 1,200 bp PCR product) and 'hly' (Listeria monocytogenes-specific, 


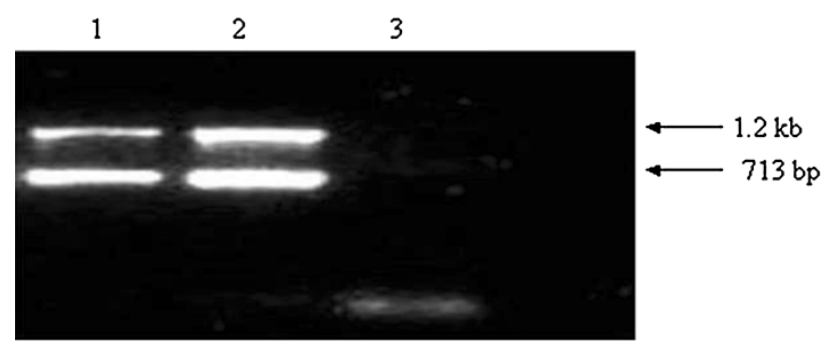

Lanes : 1, Lm ATCC 7644;2, Lm Scott A; 3, Negative Control

Fig. 4 Multiplex PCR assay using two pairs of primers targeted against $16 S$ rRNA and Hly

713 bp PCR product) since these two primer pairs consistently amplified the specific product. Our previous trials during standardization using the PCR amplification conditions of initial denaturation at $95^{\circ} \mathrm{C} / 4$ min followed by 35 cycles each of denaturation at $95{ }^{\circ} \mathrm{C} / 30 \mathrm{~s}$, annealing at $60{ }^{\circ} \mathrm{C} / 1 \mathrm{~min}$ and extension at $72{ }^{\circ} \mathrm{C} / 1 \mathrm{~min}$ followed by final extension at $72{ }^{\circ} \mathrm{C}$ for $5 \mathrm{~min}$ led to the amplification of 1,200 bp product specific for $16 S$ rRNA gene of Listeria and $713 \mathrm{bp}$ product specific for hly gene of Listeria monocytogenes (Fig. 4, Lanes 1 and 2). The multiplex PCR based on $16 S$ rRNA and ' $h l y$ ' genes was successfully applied to selected spiked and natural market dairy food samples for detection of Listeria monocytogenes that forms the subject of a separate communication.

From the foregoing presentation, it can be concluded that the multiplex PCR assay developed with two sets of primers targeted against $16 S r R N A$ and ' $h l y$ ' genes could be extremely valuable and of considerable practical utility in dairy industry for monitoring dairy foods for L. monocytogenes and hence could help in protecting the health of the consumers against this high-risk food pathogen.

Acknowledgments The work reported here is part of the DBT sponsored project on "PCR Kits" vide Sanction No. BT/PR/958/PID/ $23 / 028 / 98$. The authors duly acknowledge the financial support received from Department of Biotechnology, Govt. of India and also to The Director, NDRI, Karnal for providing the necessary infrastructure. The technical assistance provided by Mr. Inder Kumar is also acknowledged.

Conflict of interest The authors report no conflicts of interest.

Open Access This article is distributed under the terms of the Creative Commons Attribution License which permits any use, distribution, and reproduction in any medium, provided the original author(s) and the source are credited.

\section{References}

Barry T, Powel R, Gannon F (1990) A general method to generate probes for microorganisms. Biotechniques 8:233-236

Bubert A, Kohler S, Goebel W (1992) The homologous and heterologous regions with in the 'iap' gene allow genus and species specific identification of Listeria spp. by polymerase chain reaction. Appl Environ Microbiol 58:2625-2632

Bubert A, Hein I, Rauch M, Lehner A, Yoon B, Goebel W, Wagner M (1999) Detection and differentiation of Listeria spp. by a single reaction based on multiplex PCR. Appl Environ Microbiol $65: 4688-4692$

CDC (2000) Food borne outbreak of Listeriosis associated with pork tongue jelly. Morb Mortal Weekly Rep 49:221-222

Chakraborty T, Domann E, Hartl M, Goebel W, Notermans S (1992) Coordinate regulation of virulence genes in Listeria monocytogenes requires the product of the prf A gene. J Bacteriol 174:568-574

Cooray KJ, Nishibori T, Xiong H, Matsuyama TC, Fujita M, Mitsuyama M (1994) Detection of multiple virulence-associated genes of Listeria monocytogenes by PCR in artificially contaminated milk samples. Appl Environ Microbiol 60:3023-3026

Czajka J, Bsat N, Piani M, Russ W, Sultana K, Weidman M, Whitaker R, Batt CA (1993) Differentiation of Listeria monocytogenes and Listeria innocua by $16 S$ rRNA genes and intraspecies discrimination of Listeria monocytogenes by Random Amplified Polymorphic DNA Polymorphism. Appl Environ Microbiol 59:304-308

Dalton CB, Austin CC, Sobel J (1997) An outbreak of gastroenteritis and fever due to Listeria monocytogenes in milk. N Engl J Med 336:100-105

Deneer HG, Boychuk I (1991) Species-specific detection of Listeria monocytogenes by DNA amplification. Appl Environ Microbiol 57:606-609

Fluit AC, Torensma R, Visser MJC, Aarsman CJM, Poppelier MJJG, Keller BHI, Klapwijk P, Verhoef J (1993) Detection of Listeria monocytogenes in cheese with the magnetic immuno-Polymerase Chain Reaction assay. Appl Environ Microbiol 59:1289-1293

Gopo JM, Melis R, Filipska E, Filipski J (1988) Development of a specific biotinylated DNA probe for rapid identification of Salmonella. Mol Cell Probes 2:271-280

Kathariou S, Metz P, Hof H, Goebel W (1987) Tn916-induced mutations in the hemolysin determinant affecting virulence of Listeria monocytogenes. J Bacteriol 169:1291-1297

Khan S, Sujath S, Harish BN, Praharaj I, Parija SC (2011) Neonatal Menigitis due to Listeria monocytogenes: a case report from Southern India. J Clin Diagn Res 5(3):608-609

Klein PG, Juneja VK (1997) Sensitive detection of viable Listeria monocytogenes by reverse transcription-PCR. Appl Environ Microbiol 63:4441-4448

Klijn N, Weerkamp AH, De Vos NM (1991) Identification of mesophilic lactic acid bacteria by using PCR aplified variable regions of $16 S$ rRNA and specific DNA probes. Appl Environ Microbiol 57:3390-3393

Kuhn M, Goebel W (1989) Identification of extracellular protein of Listeria monocytogenes possibly involved in intracellular uptake by mammalian cells. Infect Immun 57:55-61

Kumar A, Grover S, Batish VK (2012) Monitoring paneer for Listeria monocytogenes - a high risk food pathogens by multiplex PCR. African J Biotech 11(39):9452-9456

Kumar A, Grover S, Batish VK (2014) A multiplex PCR assay based on $16 S$ rRNA and hly for Rapid Detection of L. monocytogenes in Milk. J of Food measurement and characterization. doi:10.1007/ s11694-014-9176-5

Lin CK, Tsen HY (1996) use of two 16S rDNA targeted oligonucleotides as PCR primers for the specific detection of Salmonella in foods. J Appl Bacteriol 80:659-666

Maureau P, Derclaye I, Gregorie D, Janssen M, Cornelis GR (1989) Campylobacter species identified on polymorphism of DNA encoding rRNA. J Clin Microbiol 27:1514-1517

Norton DM, Batt CA (1999) Detection of viable Listeria monocytogenes with a $5^{\prime}$-Nuclease PCR assay. Appl Environ Microbiol 65:2122-2127 
Portnoy DA, Chakraborty T, Goebel W, Cossart P (1992) Molecular determinants of Listeria monocytogenes pathogenesis. Infect Immun 60:1263-1267

Pospiech A, Neikmann B (1995) A versatile quick preparation of genomic DNA from Gram-positive bacteria. TIG 11:217-218

Sheehan B, Kocks S, Dramsi S, Gaulin E, Klarsfeld A, Mengaud J, Cossart P (1994) Molecular and genetic determinants of the Listeria monocytogenes infectious process. Curr Top Microbiol Immunol 192:187-216

Sun AN, Camilli A, Portnoy DA (1990) Isolation of Listeria monocytogenes small plaque mutants defective for intracellular growth and cell-to-cell spread. Infect Immun 58:3770-3778

Tirumalai PS (2013) Listeriosis and Listeria monocytogenes in India. Wudpecker J Food Technol 1(6):98-103

Vinothkumar R, Arunagiri K, Sivakumar T (2013) Studies on pathogenic Listeria monocytogenes from marine food resources. Int J Curr Microbiol App Sci 1(1):86-93

Wagner M, Lehner A, Klein D, Bubert A (2000) Single strand confirmation polymorphisms in the hly gene and polymerase chain reaction analysis of a repeat regain in the iap gene to identify and type L. monocytogenes. J Food Prot 63:332-336
Wang RF, Cao WW, Johnson MG (1991) Development of $16 S$ rRNA based oligomer probe specific for Listeria monocytogenes. Appl Environ Microbiol 57:3666-3670

Wang RF, Cao WW, Johnson MG (1992) 16S rRNA based probes and polymerase chain reaction method to detect Listeria monocytogenes cells added to foods. Appl Environ Microbiol 58:2819-2831

Wiedmann M, Barany F, Batt CA (1993) Detection of Listeria monocytogenes with a nonisotopic polymerase chain reaction assay. Appl Environ Microbiol 59:2743-2745

Witham PK, Yamashiro CT, Livak KJ, Batt CA (1996) A PCR based assay for detection of Escherichia coli shiga like toxin genes in ground beef. Appl Environ Microbiol 62:1347-1353

Wuenscher M, Kohler S, Bubert A, Gerike U, Goebel W (1993) The iap gene of Listeria monocytogenes is essential for cell viability and its gene product, $\mathrm{p}^{60}$, has bacteriolytic activity. J Bacteriol 175:3491-3501 